стає вже іншою - красивою, цікавою, сильною та багатою. Таким чином, щоб поставити себе у центр уваги інших людей, треба з себе зробити взірець, ідеал, цінність, замість себе «послати» важливий для інших персонаж. Найпростіше це зробити за допомогою мистецтва конструювання особливої реальності, моди. Ставши самостійною реальністю, мистецтво у широкому сенсі сприяло тому, що людина навчилася бачити і переживати себе як особливий твір, грати різні ролі (красивої жінки, успішної людини і т. д.). Все це дозволяє йому розраховувати на увагу інших, і не просто увагу, а потрібне відношення до себе - подив, захоплення, заздрість і т.д. [3, с. 104]

\title{
Література:
}

1. Алексеенко Л.В. Социология моды: классический социологический дискурс о моде. Актуальные проблемы гуманитарных и естественных наук. 2012. № 6. С. 284-288.

2. Гофман А.Б. Мода и люди. Новая теория моды и модного поведения.- М.: Книжный ддом «Университет», 2013. 228 с.

3. Розин В.М. Мода как культурно-семиотический и психологический феномен. Культурология: дайджест/Рос. акад. Наук, ин-т науч. информ.- М., 2010. 225 с.

4. Тканко 3. Мода в Україні XX століття. - Л. : Артос, 2015. 236 с.

DOI https://doi.org/10.30525/978-9934-26-004-9-7

\section{КІНЕЦЬ ІСТОРІЇ МИСТЕЦТВА ТА КІНЕЦЬ КРИТИКИ ЯК ТЕОРЕТИЧНІ СЮЖЕТИ КІНЦЯ ХХ І ПОЧАТКУ ХХІ СТОЛІТТЯ}

\author{
Калугер А. О. \\ асистент кафедри історії мистеитвва \\ Київського національного університету імені Тараса Шевченка \\ м. Київ, Украӥна
}

Особливої актуальності теоретичні сюжети «кінця історії мистецтва» набули в 1980 році після публікації праці Ханса Белтінга «Кінець історії мистецтва?» Вже тоді ним продублювалася теза щодо кінця класичної історії мистецтва і перетворення ії на історії образів. Наступні 40 років академічне мистецтвознавство було обернене в бік перетворення традиційної історії мистецтва на візуальні студії, дослідження образної 
культури та історію рецепції. Історія мистецтва як «історія шедеврів», виставкових проєктів, музеїв та мистецьких видань поступилася місцем дослідженням загального культурологічного характеру та візуальним студіям.

За рахунок інтернетизації мистецького письма та розчинення актуальної історії мистецтва в критичній теорії інтернету, що арткритика, що історія мистецтва, набули нових глобалізованих рис, таких як: анти-гранд-наративність, фокусування на локальних сюжетах і темах, «новому формалізмі», дослідження нової медіальності, феміністичних та пост-колоінальних студіях, теорії антропоцену та пост-гуманістичних студіях. В цих тенденціях прослідковувалося розбивання на темисюжети, а відтак - стверджувалася неможливість відтворення нової, глобальної, загальнонаціональної історії мистецтва, не враховуючи досвід аналітичної деконструкції історії мистецтва перерахованими сюжетами.

Щодо «кінця критики», то ця тема стала найбільш тиражованою серед іiі теоретиків після виходу у 2004 році статті Бруно Латура «Чому критика випарувалася? Від реалій фактичних до реалій дискурсивних». До цього були також значні події: дискусія «Актуальний стан критики» в журналі October, вихід збірника симптоматичних есеїв «Криза критики» в редакції Моріса Бергера i, звісно, класичної праці Джеймса Елкінса, «Що сталося з арт-критикою?».

Ми могли б виділити такі теоретичні моделі сюжету «кінця критики»: для Люка Болтанскі [2, с. 26] кінець критики відбувся як кінець ії як універсального деінституціоналізатора, кінцем критичної ролі деконструкції.

Рафаель Рубінштейн [6, с. 14], в свою чергу, запропонував гіпотезу щодо того, що можливо «критичний дух» направлений не на ту ціль. Відтак, кінець критики був не скільки кінцем, скільки ревізією.

Для Бруно Латура [5, с. 22] кінець критики був в перевиробництві гуманітаристики та сучасній особі критика, який існує в крихкому світі втраченого факту і дискусії про теорію критики перетворилися на розмови про політику жестів і їхню соціальну сконструйованість.

Гел Фостер проголосив найбільш амбітну тезу 3-поміж усіх представлених [4], а саме - появу посткритичиної території гуманітаристики. Головними складовими іiі якої були: відмова від будь-яких самодостатніх супер-его в критиці, дисциплінарна формалізованості, заборона на «адвокатство художників».

Для Джеймса Елкінса питання формулювалося наступним чином: критика перебуває в стані глобальної інфляції тексту за рахунок 
інтернетизації, а відтак вона втратила своє чітке фахове підгрунтя [3, с.27]. Критики вступили в боротьбу за аудиторію 3 популярними виданнями і глянцевими журналами, почавши орієнтуватись на те, що критерій якості - не дискусійний вплив, а кількісний показник, що разюче змінило жанри критики.

Відтак, підсумувавши досвіди розгортання цих двох теоретичних сюжетів, ми могли б підсумувати, що як критика, так і історія мистецтва, знаходяться на рівні розробки свої аналітичних стратегій та шукають нові гуманітарні території для своєї теоретичної реформації. Подальшим завданням для дослідників стане дослідження цих нових територій i модифікацій як історії мистецтва, так і критики - задля створення нових критеріїв оцінки мистецтва, які відповідатимуть актуальному культурному моменту.

\section{Лiтература:}

1. Berger M. The Crisis of Criticism / Berger., 1998. - 192 c.

2. Boltanski L. On Critique. Sociology of Emansipation / Boltanski., 2011. $-200 \mathrm{c}$.

3. Elkins J. What Happened to Art Criticism? / Elkins., 2003. - $100 \mathrm{c}$.

4. Foster H. Post-Critical [Електронний ресурс] / Foster // October. 2012. - Режим доступу до ресурсу: https://brooklynrail.org/ 2012/12/artseen/post-critical.

5. Latour B. Why Has Critique Run out of Steam? From Matters of Fact to Matters of Concern / Latour., 2004. - 117 c.

6. Rubinshtein R. Critical Mess: Art Critics on the State of their Practice / Rubinshtein., 2006. - 249 c. 